\title{
O memorial no espaço da formação acadêmica: (re)construção do vivido e da identidade
}

\author{
Jane Quintiliano Guimarães Silva*
}

\section{Resumo}

Toma-se, como objeto de discussão, a escrita de memoriais de professores em formação inicial, alimentada pelas açóes do lembrar e do recordar, das quais emergem movimentos discursivos que póem em cena a atuação de um sujeito que reflete sobre si e sobre seus saberes profissionais. O memorial, nesse quadro, é visto como um expediente metodológico produtivo por proporcionar ao pesquisador uma compreensão acerca dos movimentos do processo da formaçáo identitária profissional, a partir do ponto de vista do professor, guiado, portanto, pelos olhos desse sujeito. Nessa atividade de escrita, identifica-se um jogo de atuaçáo enunciativa e metadiscursiva que revela, ao leitor, o tipo de engajamento que o sujeito cria com o seu próprio dizer e/ou com o dizer do outro, com o seu saber profissional.

Palavras-chave: Memorial. Formação identitária. Ações metadiscursivas.

* Doutora em Linguística pela Universidade Federal do Minas Gerais. Professora do Departamento de Letras da PUC MINAS. 


\section{Introdução}

Falar sobre a minha a vida escolar, minha vida acadêmica é fazer uma espécie de um livro de recordações, é contar coisas boas e más de nossa experiência. É olhar para um tempo longe e trazêlo para mais perto, é como se desse um "zoom" em momentos da nossa história. Fico muito envolvida com esse trabalho e também muito emocionada porque falo de um tempo da minha vida que somente agora entendo como foi e é importante para a minha profissão.

A epígrafe de que lanço mão para abrir as reflexôes deste artigo é parte da introdução de um memorial, escrito por uma professora em formação inicial, retirado de um corpus constituído de 46 textos, exemplares do gênero memorial, produzidos por graduandos em Letras, como trabalho de conclusão de curso ${ }^{1}$.

Reconhece-se, na passagem em foco, um narrador que, metadiscursivamente, dá a conhecer ao leitor, sem a densidade da chamada linguagem técnica ou da "escrita teórica", pelo menos três traços do funcionamento discursivo do gênero memorial, a saber: a finalidade comunicativa, o conteúdo temático e a postura/perspectiva que o produtor assume no curso da escrita de suas memórias, em relaçáo aos objetos narrados. Relativamente a esse último aspecto, importa pôr em destaque a figuração do narrador no processo narrativo. No fio de sua narração e, portanto, na configuração da narrativa, dá-se a emergência de um narrador, que se expressa como eu (eu-narrador), o qual narra, sob um dado ponto de vista, as suas experiências acadêmicas e profissionais. Instala-se aí um jogo enunciativo e estético, como diz Bakhtin (2003), em que eu me torno um outro da minha própria história. O eu que é narrado - objeto sobre o qual se fala, o objeto tematizado - tem, sob a sua performance, a batuta de um eu-narrador que explica ao leitor o que é narrar e sob que perspectiva discursiva pretende abordar tal objeto e, portanto, construir o universo narrado/contado. Ou seja, essa figura da encenação narrativa metadiscursivamente nos esclarece que, "Falar sobre a minha a vida escolar, minha vida acadêmica, é fazer [...], é contar [...]. É olhar para um tempo 
longe e trazê-lo para mais perto, é como se desse um "zoom" em momentos da nossa história".

Admite-se que contar e narrar são atividades discursivas e modos de dizer agenciados à luz de uma finalidade comunicativa, atualizados numa organizaçáo linguística, textual e enunciativa, regulados tanto por regras da sintaxe narrativa como por normas sociais engendradas na esfera de atividade em questão, no caso, a acadêmica. Nesse processo de construção por meio das açóes de contar ou narrar, posterior, obviamente, à existência de uma realidade supostamente passada, instaura-se o mundo representado, criado discursivamente. Relativamente à posição enunciativa daquele que conta a sua própria história de vida, tem-se aí a emergência do movimento de auto-objetivação, por meio do qual, nas palavras de Bakhtin (2003, p. 13), "o autor deve tornar-se outro em relação a si mesmo, olhar para si mesmo com os olhos do outro". Ainda, para assumir tal posição, o produtor/autor se coloca fora do mundo que é por ele construído discursivamente. Em resumo, para Bakhtin (2002, p. 360), "o mundo representado, mesmo que seja realista e verídico, nunca pode ser cronologicamente identificado com o mundo real representante, onde se encontra o autor-criador dessa imagem."

Nesse raciocínio, o mundo representado não pode nunca ser idêntico, do ponto de vista espaço-temporal, ao mundo real, àquele que representa, àquele onde se encontra o autor que criou essa imagem. Em outros termos, fabrica-se discursivamente um mundo, cuja existência não resulta de meras reproduçóes de objetos do mundo objetivo (fatos, situaçôes, figuras, pessoas, etc.), mas de um trabalho linguageiro que constrói uma realidade discursiva, fundada a partir do modo como o sujeito interpreta o "real" e significa-o no bojo de uma dada situação de interlocuçáo. Daí reconhecer a pertinência de ditos populares como: "Quem conta um conto aumenta um ponto" ou "Quem conta aumenta, mas não inventa".

Nesses parágrafos introdutórios, anuncia-se um dos fortes pressupostos tomados por mim como um esteio para perseguir o propósito investigativo deste estudo, a saber: a escrita de memoriais por professores em formaçáo inicial mostra-se relevante expediente pedagógico e metodológico para que se possa compreender, a partir do ponto de vista do professor em formação, guiado, portanto, pelos seus olhos, a construçáo de movimentos de subjetividade constitutivos do processo de sua formaçáo identitária profissional. Noutros termos, essa importância se explica pelo fato de o 
memorial oferecer ao pesquisador (ou ao professor formador) possibilidades de apreender movimentos de inscrição do sujeito no discurso. Deixam-se entrever, por meio deles, as açóes e os sentidos produzidos localmente, pelo produtor no curso de sua narrativa, bem como as vozes aí mobilizadas, as quais dialogicamente moldam a interlocução, ao mesmo tempo em que esta, por seu turno, molda-as.

Nesse processo de escrita, conforme o corpus investigado, o produtor, na construção de sua narrativa, experiencia o chamado exercício metacognitivo $^{2}$ e autoreflexivo, que se sustenta por um trabalho de avaliação ativa, de regulação e organização de conhecimentos e saberes implicados na tarefa. Desenvolve-se aí, também, a chamada autocompreensão do que ele é e do que não é, das aprendizagens e saberes que construiu ao longo da vida, o que implica a elaboração de um processo de conhecimento de si e dos significados que atribuiu aos diferentes fenômenos que mobilizam e tecem a sua vida individual e coletiva (SIGNORINI, 2000).

Em resumo, aposta-se que, no relato de suas experiências, o professor em formação, assumindo determinadas posições de sujeito e posicionamentos identitários, presumíveis, em larga medida, pelas injunçóes institucionais e pela natureza discursiva da tarefa, constrói, narrativamente, um espaço de reflexão, de rememoração, de (re)significação de experiências vivenciadas no quadro das práticas do mundo acadêmico. Realiza também um trabalho de (re)conceituação ou (re)contextualização de saberes relativos ao seu fazer acadêmico e profissional, deixando, assim, no curso de sua escrita, entrever a história de sua formação acadêmica e profissional, recortada por vieses que assinalam a sua inserção nas práticas discursivas da esfera em questão. Antes, porém, de avançar nesta exposição, ressalte-se que o mote da pesquisa em pauta aproxima-se daqueles que iluminam frentes de estudo que objetivam penetrar, de forma sistemática, no universo das práticas de formação do professor, tomando como objeto de estudo a escrita de $s i^{3}$, práticas essas atualizadas em narrativas autobiográficas ou memoriais (cf. NOVOA, 1992; FRAGO, 2002; MARTINS, 2005).

\section{Memorial: ações do recordar}

Chegamos a um ponto caro a este estudo. Falar de memória significa concebê-la sob um enfoque que enfatize a relação de interface entre a sua 
dimensão social e individual/psicológica. Sob esse enquadre, importa dizer que a noção de memória não se restringe àquela de ordem psicológica, como faculdade mental ou uma capacidade individual de natureza estritamente biopsíquica. Além desse traço, a memória, enquanto construção social, situase num espaço que medeia a ação ideológica e a experiência social que os membros de uma comunidade específica possuem acerca de suas experiências humanas. A dimensão social de que se reveste a memória pressupóe sempre uma relação de partilha cultural no seio do grupo social em questão. É social porque ela compreende um sistema de organização e mediação cultural do ato mental de recordar, de rememorar (cf. MISTAL, 2003).

Rememorar ou recordar, termos aqui intercambiáveis, fundam-se em uma operação mental, caracteristicamente individual, psicológica, que traz à baila elementos de um mundo íntimo, (inter)pessoal e cultural, os quais alimentam um quadro de referência partilhado ${ }^{4}$. Nessa acepçáo, conforme Mistal (2003) e Bartlett (1977), a memória individual, ao invés de estar subordinada à ação unificadora da coletividade, revela-se potencialmente como um espaço interpretativo, de construçáo de sentido, regulado pelas experiências emocionais e expectativas pessoais de cada indivíduo.

Em se tratando de narrativas míticas, vale salientar que a ação de recordar desempenha uma função fundamental, pois, recordar significa resgatar um momento originário e torná-lo eterno em contraposição à nossa experiência ordinária do tempo, como algo que passa, que escoa e que se perde. A recordaçáo, como resgate do tempo, confere imortalidade àquilo que ordinariamente estaria perdido de modo irrecuperável sem essa (re)atualização. Nas narrativas míticas, trazem-se de novo à presença dos deuses os feitos exemplares que forjam os heróis. E, ainda hoje, perseguimos modelos que nos colocam novamente em presença das tradiçôes dos antepassados que nos tornaram o que somos. Nessa acepção, o papel da memória não é o de simples reconhecimento de conteúdos passados, mas de um efetivo reviver, que leva em si o todo ou parte desse passado. É graças à faculdade de recordar que, de algum modo, escapamos da morte, e essa faculdade mais do que uma realidade física deve ser entendida como a realidade simbólica que cria o antagonismo-chave ao esquecimento (cf. ELIADE, 1986).

Relativamente às narrativas memoralísticas, o trabalho de recordação é uma espécie de trabalho de objetivação, mediado pela interseçáo de 
histórias pessoais, coletivas e sociais. É nesse sentido que o indivíduo é visto como sujeito que interpreta e significa o mundo, constrói para ele uma compreensão individual, povoada por sentimentos, emoçóes, impressóes, oriundas de seu universo sociocultural.

Nessa medida, talvez valha a pena beber novamente na epígrafe deste artigo, para realçar a noção que o termo recordar ganha neste estudo:

[...] Fico muito envolvida com esse trabalho (uma espécie de livro de recordaçôes) e também muito emocionada porque falo de um tempo da minha vida que somente agora entendo como foi e é importante para a minha profissão.

Em outras palavras, os memoriais consistem em um trabalho de recordação das experiências individuais que, trazidas pelos estudantes para a construçáo de seu discurso, encarnam as tonalidades sociais, históricas, culturais e afetivas, fundadas por uma carga axiológica.

Sobre isso, com Pollak (1992), observa-se que a memória também sofre flutuações em função do momento em que ela é articulada, em que está sendo objetivada e expressa. As preocupaçóes do momento constituem um elemento de estruturação da memória. Recordar as experiências vivenciadas no seio dos eventos das práticas discursivas da esfera acadêmica implica, da parte do produtor, um ato de reconhecimento do vivido, de reflexão sobre os objetos recordados, construídos discursivamente num quadro de significaçóes (e sentidos) e engendrado na rede de atividades de socialização desse sujeito. Pelo trabalho com as memórias, pode-se recordar para elaborar, problematizar algo, para, numa relação intra-subjetiva, abrir espaços para (re)significações ou novos gestos de ler o mundo em questão.

Em suma, pensar a memória numa relação de interface entre o coletivo e o singular impóe, metodologicamente, tomá-la à luz de uma orientação dialógica, que realce a sua dimensão (inter)subjetiva, a sua função social, em cuja atualização entrecruzam-se múltiplas vozes.

Deste traço - o da recordação - não se descarta o tom ficcional em que se podem inscrever os textos memoralísticos, abrigando aí o trabalho da imaginação, da representação e/ou (re)configuração dos objetos narrados. Trata-se de conceber a ficcionalidade em um sentido alargado, fruto da atividade de linguagem, resultante da construção discursiva de uma dada 
realidade, ficcionalizada mediante o entrecruzamento do autobiográfico, suposto real, e do maravilhoso/ficcional.

A passagem que se segue, retirada do corpus da pesquisa, oferece-nos uma ilustração desse exercício ficcional pela via do rememorar.

Era uma vez uma menina que morava em um interior muito distante da cidade, onde não havia escola nem livros, somente havia trabalho na roça. Ela saiu de lá para trabalhar com uma família rica, onde teve a oportunidade de conhecer as primeiras letras. Ler e escrever não eram obrigação, mas diversão. Somente, aos doze anos, veio-lhe a escola, e de lá não quis mais sair. Quando contei essa história a minha professora de literatura, ela não acreditou, porque ela dizia que eu lia bem e conhecia muitos livros. Às vezes, também não acredito que estou concluindo um curso superior e que me tornarei professora de português e de literatura. Isso não é ironia do destino ou conto de fadas, apenas mais uma história de muita luta e que muitos me ajudaram a construir e a eles dedico este trabalho.

Esse trecho, intitulado Para aqueles que acreditaram em mim, encontra-se na segunda página de um dos memoriais em exame, afigurando-se como uma dedicatória, recurso comumente adotado por grande parte dos textos analisados, traduzido na forma de agradecimento ou de dedicatória. A produtora, ao iniciar a suas memórias por era uma vez, parece penetrar no mundo da ficção, produzindo um efeito que se aproxima ao dos contos maravilhosos. $\mathrm{Na}$ abertura, que se estende até o termo diversão, ecoa uma voz "alheia", que intenta promover um distanciamento/afastamento no tempo e no espaço, entre aquele narra e o que é narrado e, ainda, entre ambos e o seu espectador/leitor. Um distanciamento criado pela disjunção do tempo da enunciação, da ação do narrar, e o tempo do fato narrado. A reconstituição de um passado, pelo tom ficcional, parece robustecer a narrativa dos fatos vividos e ali em construção, porque contados. O passado parecer servir como forma de reflexão de um presente. Narra-se a história do outro, figura colhida em um real e transformada (ficcionalizada) em um personagem (do "eu" 
quando menina) cuja aventura soa incrível ou como um sonho, para a qual se traça um final feliz.

Considerados a abertura do trecho, o seu restante e, ainda, a natureza do texto em produção, reconhece-se ali uma estratégia discursiva, mediante a qual se promove a alternância de dois modos de visão do mundo: a do "real" e a do "ficcional". Na passagem da terceira pessoa para a primeira, tem-se, igualmente, uma estratégia gerada num jogo de linguagem, criando uma alternância de posiçóes enunciativas: o narrador transforma-se em eunarrador, figuras que se (con)fundem entre si e com o objeto narrado. Ou seja, pela via da recordação, o real e o inventado dialogam na conjugação de duas histórias, formuladas num processo metadiscursivo: uma história dentro de outra história é tecida na memória. $\mathrm{Na}$ oscilação da figuração narrativa, o eu e o outro são duas faces de uma mesma moeda, na medida em que a experiência pessoal, nessa cena, é fonte geradora de um mundo ficcional: o que é da ordem do factual é amalgamado com o ficcional.

Nesse trabalho discursivo, o elo que une esses universos no mundo narrativo é bordeado também pela opacidade das expressóes "lá" e "quis"; em "Somente, aos doze anos, veio-lhe a escola e de lá não quis mais sair" interpenetram-se polissemicamente os dois universos: lá se estende e se perde no tempo e no espaço de uma escola, porque dela nunca quis sair e nunca saiu a menina do interior e aquele narra; quis, expressão verbal, por não trazer uma marca formal que distinga as figuras (e não-pessoa, tema da abertura da narrativa) da enunciação - ela quis ou eu quis -, acaba sugerindo uma ambivalência na cena enunciativa, na figuração do sujeito, uma dualidade ou duplicidade fundada no encontro do eu-narrador com o outro eu que é narrado, com o qual se identifica.

Esse gesto na tessitura da narrativa nos remete também a estudos de Ricouer (1997), particularmente, a Tempo e Narrativa, trabalho em que esse autor concebe as narrativas - ficcionais, memoralísticas e autobiográficas - como espaço em que uma identidade se afigura náo apenas como uma identidade pessoal, mas principalmente como identidade narrativa. Irrompe uma fusão, na medida em que uma figura do discurso construída à luz das impressôes, da imaginação, do ponto de vista de um indivíduo, na encenação narrativa, ganha vida. Essa relação estreita e difusa entre uma identidade pessoal e uma identidade narrativa é, para o autor: 
O frágil rebento oriundo da uniấo entre a história e da ficção é a atribuição a um indivíduo ou a uma comunidade de uma identidade específica que podemos chamar de identidade narrativa. $\mathrm{O}$ termo "identidade" é aqui tomado no sentido de uma categoria prática. [...] Responder à questão "quem?", como o dissera Hannah Arendt, é contar a história de uma vida. A história narrada diz o quem da ação. A identidade do quem é apenas, portanto, uma identidade narrativa. Sem o auxílio da narração a problemática da identidade pessoal está, com efeito, fadada a uma antinomia sem solução: ou se coloca um sujeito idêntico a si mesmo na diversidade de seus estados, ou se considera, na esteira Hume e Nietzsche, que esse idêntico é somente uma ilusão substancialista, cuja eliminação só se revela num puro diverso de cogniçôes, de emoções e de voliçóes. Desaparece o dilema se substituímos a identidade compreendida no sentido de um mesmo (idem) pela identidade no sentido de um ipse; a diferença entre idem e ipse não é senão a diferença entre uma identidade substancial ou formal e a identidade narrativa. (RICOEUR, 1997, p. 424-425).

O sujeito que se anuncia, no memorial, investe-se de uma posição identitária, narrativamente ou discursivamente construída, cuja emergência dá-se na (e pela) enunciação escrita. Ora, nesse movimento, a experiência vivida, porque contada, porque representada, modifica-se, assim como o seu autor. Escrever a própria história configura-se como a ação de buscar conhecer a si mesmo, por meio da (e na) qual o sujeito vai (re)construindo uma trajetória, que não é linear ou mensurada objetivamente. Mas, sim, fundada numa temporalidade engendrada na memória que, plasticamente, recorta o passado numa interface com o presente. Ao (re)interpretar o passado ou ao (re)vivê-lo pelo discurso, sob a ótica do presente ou em função de projetos futuros, o sujeito que aí se mostra é afeito a desdobramentos. Tem-se um sujeito dotado de uma identidade não homogênea, única e estável, mas, sim, plástica e dinâmica, resultante da constituição de um eu que, atravessado por uma vivência histórica, revela-se, no curso da narrativa, em constante remanejamento, pois, ao refletir sobre o passado com sua 
presente formação pessoal, traz consigo reflexões e observaçóes que podem assegurar-lhe um novo olhar.

\section{Narrativa: construção e circulação de saberes}

No bojo deste estudo, como se pode notar, toma-se a narrativa como uma forma discursiva de organizar as experiências humanas. Pela narrativa engendrada no seio das práticas discursivas dos gêneros discursivos - mitos, casos, contos, fábulas, depoimentos, crônicas, notícias, confissões, biografias, autobiografias, lendas, fábulas, depoimentos, memoriais, crônicas, etc.-, as pessoas estruturam os seus dizeres e saberes, constroem uma visão de mundo, negociam e socializam significados/sentidos (cf. BRUNER, GREENFIELD; OLVER, 1966).

Nessa linha de discussão, afasta-se a possibilidade de tratar a narrativa sob o recorte das tipologias de texto, para as quais a narrativa é um construto teórico, de natureza estritamente linguística, formalmente concebida como uma sequência textual.

$\mathrm{Na}$ vertente investigativa proposta, a narrativa, forma discursiva de produção e de circulação de saberes, ganha um espaço legítimo entre os diversos discursos produtores de saber. Conforme defende Lyotard (2002), por não predominarem as exigências típicas de um saber científico, como a demonstração e a verificação, por exemplo; por insistir na irredutibilidade da pluralidade do mundo, o saber narrativo é marcado pela não rigidez e traz as injunçóes do aqui e agora, em interlocução com uma memória que (re)constrói o passado. Dessa perspectiva, ficção e teoria, na constituição do saber narrativo, conjugam-se num movimento de permanente construção do objeto abordado, em que se podem agregar os lapsos, as contradiçóes e os intervalos de informaçóes e reflexóes propiciados pelo próprio objeto de análise, como se intentou há pouco ilustrar.

Nessa direção, Burke (1992), no artigo, "A história dos acontecimentos e o renascimento da narrativa", refletindo sobre o fazer do historiador, expóe que o modo narrativo passa a ocupar o lugar do analítico, resultante da mudança da metodologia relativamente à construçáo dos objetos da história. Ou seja, pela própria concepção da escrita histórica como gênero narrativo, marcada pela categoria temporal, a abordagem do historiador se modifica em favor dos acontecimentos que antes não tinham importância para a análise, 
reforçando a sua função que é a de sempre estar contando uma história. E o que é mais importante: essa história está sujeita a interpretaçóes parciais, marcadas pelo olhar subjetivo, às vezes circunstancial, pelo fato de estar o narrador se utilizando de um ponto de vista pessoal e estar ciente (ou não) das múltiplas vozes que entram nesse processo criador.

Nessa atividade, narrar memórias pressupóe uma ação autoreflexiva e autobiográfica, em cuja atualização, no seio do discurso, pode-se deixar vir à cena - enunciativa e /ou discursiva - a imbricação de movimentos por meio dos quais o narrador conjuga situaçóes vividas àquelas por ele criadas e/ou reinventadas no ato de narrar. Narrando, reinventa-se o acontecido, projetando o futuro e remodelando o passado. Nesse sentido, resumindo, o passado afigura-se no presente como forma de reavaliação. O presente, momento em que se funda o processo da enunciação, da construção do objeto narrado, dá a tonalidade às lembranças. Nas palavras de Bosi (2001, p. 20): "Lembrar não é reviver, mas re-fazer. É reflexão, compreensão do agora a partir do outrora, é sentimento, reapariçâo do feito e do ido, nâo sua mera repetição."

Para acentuar a concepção de narrativa aqui adotada, na interpretação dada ao memorial dos professores, trago também as palavras de Walter Benjamim, para quem,

A narrativa segue o curso da vida, ela náo se explica à parte da vida, simplesmente flui. Na medida em que a história é narrada, os fatos surgem acompanhando a memória do narrador, 'que não se preocupa com o encadeamento exato de fatos determinados, mas com a maneira de sua inserção no fluxo insondável das coisas'. (BENJAMIM, 1994, p. 209).

Ainda, segundo esse autor,

[...] a narração não tem a pretensão de transmitir um acontecimento, pura e simplesmente (como a informação faz) integra-o à vida do narrador para passá-lo ao convite como experiência. Nela ficam impressas marcas do narrador como os artigos das mãos do obreiro no vaso de argila. (BENJAMIM, 1994, p. 68). 
Narrar as experiências do cotidiano (vividas, reinventadas) consiste, como assinala Benjamin, em um trabalho que se aproxima do artesão, na medida em que o narrador confere uma forma à matéria narrável, matéria essa que é a própria vida humana, a experiência vivida, eivada pelas tonalidades do fazer narrativo. Nesse sentido, a narrativa é vista como uma atividade social do homem, constitutiva da sua humanizaçáo, por meio da qual o narrador não transmite o "puro de si" do objeto narrado como o faria em um relatório técnico. Nessa construção discursiva, a narração das memórias é um trabalho que implica refletir sobre o objeto narrado, o acontecimento em cena, a partir de uma posição/perspectiva discursiva e enunciativa - falar de um dado lugar, representá-lo de acordo com a sua finalidade comunicativa e seus interlocutores.

Se se admite que recordar a experiência vivida é uma ação que implica reflexão, regulada por crenças, opinióes e valores, na qual se imbricam o íntimo/pessoal e o social, reitera-se, nesses termos, que o mundo narrativo é criado sob a batuta de um (eu) narrador que recorta e constrói uma realidade sob o enquadre de um aqui e agora da atividade mesma de narrar. Numa visão bakhtiniana, instaura-se uma posição refletida e refratada por uma outra posição axiológica, mesclada pelo viés de uma experiência histórica, traçado pelo prisma do narrador, nas memórias em exame, do eu-narrador.

\section{O memorial no espaço da formação acadêmica}

O memorial, no contexto do mundo acadêmico, define-se como um gênero discursivo que se atualiza mediante açóes de linguagem, empreendidas pelos alunos em resposta a uma demanda objetiva do domínio acadêmico. Uma demanda, do ponto de vista institucional, no quadro do curso, circunscrita a um conjunto de práticas de ensino de uma dada disciplina pedagógica. Esta confere à atividade, produção de memorial, o estatuto de pré-requisito (dentre outros) para o futuro professor mostrar-se apto a assumir o lugar de professor no mundo da docência.

Nessa linha de raciocínio, seguindo um enfoque bakhtiniano, o gênero de discurso pode ser visto como uma ferramenta que vai mediar e viabilizar a inserção e a atuação do sujeito nas práticas discursivas da esfera social em questão. Isso está diretamente ligado à necessidade, por parte dos sujeitos, de apropriação de saberes (não só os técnicos, mas igualmente aqueles que 
remetem às normas sociais que regulam suas atividades na esfera social em foco), que legitimarão a sua pertença à comunidade acadêmica (cf. ASSIS; SILVA, 2007).

No espaço da formação acadêmica, o memorial, se visto como uma prática do narrar a história pessoal, afigura-se, nesse cenário, como dito, importante ferramenta metodológica por meio da qual se pode apreender o vínculo entre as maneiras de o sujeito compreender a si mesmo e o mundo que o cerca e, a partir desse processo, elaborar suas narrativas, isto é, suas memórias.

Retomando Ricuoer (1997a) para realçar o que foi exposto, a narrativa pode e dá ao sujeito não apenas a oportunidade de pensar sobre si, mas também de contar sobre si. Esclarece também esse autor que a vida narrada não é a vida vivida. A experiência da narração é aquela que transforma o vivido. Isso consiste na configuração dos acontecimentos da vida em um enredo que, por sua vez, permite uma (re)figuração dessa mesma vida. Essa capacidade da vida contada tornar-se uma referência de identidade (a identidade narrativa) é que dá ao autor dos textos memoralísticos a satisfação de ver-se a si mesmo representado enquanto personagem de uma história que ele viveu e que pode contar. Nesse cenário, autor, personagem e narrador se fundem em uma só figura; diria em um só sujeito, sem, no entanto, serem os mesmos, ou seja, aquele que viveu e aquele que conta essa vida. Poderia dizer, como se descreveu acima, que o personagem do memorial é o autor se inventando também, daí não se poder dizer que a vida lembrada e narrada seja a vida vivida.

Para ilustrar essa observação, consideremos a passagem abaixo, retirada do corpus pesquisado:

Em Letras, descobri a Linguística, segmento táo instigante que me fez pensar sobre minhas relaçóes com a própria língua, seja ela falada ou escrita. Descobri que a gramática não é a rainha majestosa como pregada há tanto tempo. Ela deve estar em função da pessoa e não esta em função dela. Descobri uma outra visão sobre a literatura também. Nenhuma obra mexeu mais comigo que Dom Casmurro. Estava em outra fase da minha vida. Já mais adulto e cheio de responsabilidade. Mais uma vez aparece Machado 
de Assis e me inquieta com as suas palavras. Lembrome de que enquanto lia, ia também me imbuindo das teorias literárias que me auxiliavam na leitura, as teorias linguísticas que me permitiram um outro olhar sobre a construção textual da obra [...]

O eu-narrador que se mostra nesse trecho é uma figura que narra a história de um eu que se desloca, por meio de análise, promovendo um distanciamento entre o papel vivido do autor e suas próprias experiências. Irrompe-se, nesse momento de enunciação, uma posiçãosujeito que se mostra apto, capaz e autorizado a dizer o que diz. Emerge, nessa cena narrativa, uma identidade, a partir da qual fala ou anuncia uma voz. Ou seja, instala-se um eu que, investido do lugar social - estudante universitário, professor em formação - reflete sobre os saberes, conhecimentos teóricos, conceituais, crenças e opinióes, rotinas e/ou práticas, construídos no curso de suas açóes na rede de atividades acadêmicas. Essa posição-sujeito ganha outros contornos, que parecem filiar-se a práticas discursivas da esfera da ciência que advogam concepçóes de língua, gramática, literatura, leitura e escrita as quais tendem a afastar-se daquelas cujo objeto, historicamente, na esfera escolar, foi sacralizado e, por ora, está em questão. Pode-se dizer que o eunarrador em cena, marcado por essa posição-sujeito, traz discursivamente na sua constituição subjetiva, vozes que problematizam uma formação de professor que deixou de fora a ação do sujeito (no caso, o aprendiz) na construção e apropriação de seus saberes.

Reconhecem-se tais movimentos na materialidade do texto, expressos nos modos de dizer do eu-narrador. Toma-se, como exemplo, a seleção dos recursos linguísticos, como, descobri; me fez pensar; uma outra visão; me inquieta; me imbuindo das teorias literárias; me permitiram um outro olhar, na formulação de alguns enunciados, que semanticamente, no fluxo da enunciação, evocam um tom de mudança, de transformação pela qual passou o graduando. São formas verbais e nominais que encerram uma carga axiológica e expressam uma interpretação e/ou atitude do eu-narrador relativamente aos saberes aí objetivados. Em suma, por meio do modo de dizer e da construção dos objetos do dizer, empreende, por parte do eunarrador, um trabalho de (re)significação de saberes e de (re)conceituação de objetos. Esses objetos do dizer, como enunciados, sinalizam o processo 
de (re)configuraçáo de posicionamentos e/ou filiaçóes discursivas e identitárias, vivenciado pelo eu que aí se mostra.

Essa ação de linguagem, a um só tempo, expressa a transformação e constituição do eu inscrito naquele que experienciou as reflexóes provocadas pela interlocuçáo com a Linguística e com a Literatura. Um eu, cuja existência discursiva ou narrativa é construída pelo narrador/autor que lembra e relata os efeitos das descobertas empreendidas pelo eu-narrado (o outro eu). Sobre isso, retomando Bakhtin (1993), ambas as figuras eu-narrador e o eu sobre o qual se fala -, nas narrativas autobiográficas e memoralísticas, irrompem num processo de auto-objetivação. Isto é, como assinalado, a escrita de memórias funda-se em um trabalho de reflexão sobre si mesmo, num movimento de subjetivaçáo, que é o de refletir sobre a condiçáo e/ou o lugar de sujeito em dada esfera de atividade. O autor/ narrador precisa dar a sua vida (objeto temático de sua narrativa) um certo acabamento, que somente alcançará se dela distanciar-se, se olhá-la de fora, se se tornar um outro em relação a si mesmo. Em resumo, retomando mais uma vez Ricouer, cria-se, nesses termos, a possibilidade de o sujeito refletir sobre si, sobre o seu lugar, sua posiçáo e papel social e identitário. Nesse processo, ao voltar-se para si mesmo, ele toma a si mesmo como objeto de reflexão.

Resumindo, esse tipo de agenciamento parece ser o fio condutor da escrita do memorial. Instaura-se um eu que reflete sobre o me (myself), elege-o como objeto, torna-se o outro, sob um viés valorativo. Isso equivale a dizer que no eu se reflete e refrata o nós/coletivo e vice-versa. Reconhece-se, na passagem em exame, que, na escrita das memórias pela via da recordaçáo, o eu-narrador náo revive o fato narrado, mas re-faz-se no processo mesmo da narraçáo, como dito. Assim, pela tomada de consciência, reflete sobre os seus saberes profissionais (e a função que têm na constituiçấo de sua formação identitária). É a assunção dessa posição identitária (ser professor em formação) que o habilita a dizer o que diz e como o faz. É, sob esse viés, que a escrita de memórias caracteriza-se como um trabalho metadiscursivo, portanto, notadamente reflexivo, realizado na forma de (re)conceitualizaçáo e/ou (re)contextualização de saberes e conhecimentos, de (re)configuraçáo de papéis e posiçóes identitárias - reflexos de seus processos de subjetivaçãol subjetividade. Como dito, a análise das manifestaçôes discursivas possibilita flagrar os processos de construçáo de sentido, na medida em que tudo o 
que se nos apresenta no mundo sócio-histórico está indissociavelmente entrelaçado com o simbólico, como propóe Bakhtin (2003).

\section{O gerenciamento de vozes na escrita do memorial}

Chegamos a outra característica do memorial: um gênero marcadamente dialógico, em cuja escrita emergem vozes que podem se digladiar e/ou se completar. Instalam-se, na composicionalidade do discurso, fios dialógicos que, em redes, tecem, ora de forma mostrada, ora não-mostrada, os discursos oriundos de domínios ali presumíveis (ciências da linguagem, literatura, pedagógico, didático, etc.), que são apropriados, conforme Bakhtin (2003), ou internalizados, de acordo com Vygotsky (1991), pelos estudantes, ao longo de seu percurso de formação acadêmica.

Ora, ao se falar de gerenciamento de vozes, numa perspectiva dialógica, abre-se a possibilidade de retomar aqui que a consciência de uma posição identitária é resultante de uma construção social, na qual se entrelaçam a memória do eu (que narra) e a memória da coletividade (o do grupo de pertença). Se, como dito, a memória do homem é constitutivamente social, histórica, cultural e simbólica e, se não há memória puramente individual, reitera-se que a memória é o imbricamento de vozes sociais, engendradas no curso dos processos de socialização pelos quais passam, contínua e permanentemente, as pessoas. E aliado a isso, a formação identitária não pressupóe algo estático, homogêneo, mas refratário às injunçóes sociais e históricas pelas (com) quais o sujeito sofre e/ou convive no processo de sua formação social.

Vejamos uma passagem, retirada do corpus, que nos permite ilustrar essas consideraçóes.

Quero buscar saberes não apenas na área de Letras para o meu aprimoramento profissional. Além dos Estudos linguísticos e literários, há também outros conhecimentos relevantes e necessários para a elaboraçáo de propostas pedagógicas, por exemplo, os conhecimentos da Pedagogia, os de Psicologia. É preciso saber sobre a legislação do ensino de educação básica, sobre as relaçóes, comportamentos e atitudes humanas. Quando fiz as disciplinas da área 
pedagógica (que foi uma pena encontrá-las somente nos estágios, porque precisamos ter mais segurança na sala de aula), passei a entender que a sala de aula, ser professor é muito mais que saber a língua portuguesa, a gramática, etc. Como explica um texto que li, e que todo professor deveria saber, pois o autor faz uma provocação, num bom sentido, de que parece que se desconhece ou ignora que por trás do trabalho de cada professor, em qualquer sala de aula do mundo, estáo séculos de reflexóes sobre o ofício de educar. Mesmo os profissionais de ensino que não conhecem a obra de Aristóteles, Russeau ou Durkheim trabalham sob a influência desses pensadores, na forma como foi incorporada à prática pedagógica, na organização do sistema escolar, aos conteúdos dos livros didáticos, ao currículo de formação dos professores.

Esse trecho, retirado do capítulo de conclusão de um dos memoriais examinados, dá-nos a conhecer a emergência de movimentos polifônicos provocados pelas alusóes, citaçóes, paráfrases, comentários, ironias, etc., por meio dos quais se veem nuances do processo da formação identitária profissional, esta atualizada por uma identidade narrativa.

Trata-se de um movimento discursivo e enunciativo, fundado na orquestração de vozes que exige do eu-narrador um gerenciamento dos discursos em cena, isto é, na gestão dos modos de dizer, postos em sintonia (ou não) com as posiçóes subjetivas por ele assumidas no mundo narrativo. Em outras palavras, na assunção de posições subjetivas (conscientes ou não) ressoam vozes que sinalizam de que lugar fala quem as mobiliza.

Flagram-se, nesse trecho, fragmentos de discursos que, na esfera das produções acadêmicas de formação profissional, conjugam-se para projetar um perfil profissional dotado de múltiplos saberes. Isso ecoa (ressoa) na voz do eu-narrador, que assume, do ponto de vista identitário, posição de quem pode problematizar e/ou reivindicar algo, que pode dizer o que diz na enunciação em curso (cf. SILVA; MATÊNCIO, 2005).

Nessa enunciação, identifica-se a emergência de um sujeito fundado a partir de uma pluralidade de posiçóes, presumíveis e/ou condizentes com os jogos de discurso engendrados na esfera de atividade em questão. Consideramos primeiramente a inserção de um comentário feito pelo eu- 
narrador em off, marcado pelos parênteses, o qual, antes de ser uma mera explicação, é um comentário avaliativo, uma ação metaenunciativa, balizada pela descoberta feita na experiência. Por meio desse comentário, o sujeito problematiza o currículo do curso em exame, que, aos seus olhos, parece não ser construído de forma orgânica.

[...] Quando fiz as disciplinas da área pedagógica (que foi uma pena encontrá-las somente nos estágios, porque precisamos ter mais segurança na sala de aula), passei a entender que a sala de aula, ser professor é muito mais que saber a língua portuguesa, a gramática, etc. [...] ( grifos nossos para o trabalho de análise do enunciado)

Pelo que se anuncia nos parênteses, pode-se apreender a emergência de uma voz que revela uma ambivalência - a confluência/clivagem da memória, o presente (re)configurando o passado, problematizado pela historicidade do aqui e agora. Fala-se, por um lado, do ponto de vista de aluno (de um agente expresso pela forma verbal - fazer), que lamenta o lugar ocupado pela disciplina no curso de sua formação pedagógica; por outro, do ponto de vista do futuro professor (de um agente expresso e gerado pelo saber), que reconhece a importância da construção de saberes pedagógicos e didáticos presumíveis para sua atuaçáo em sala de aula, os quais não deveriam ocorrer somente em situação de estágio.

Ainda, identifica-se, como outra manobra de gerenciamento de vozes bem como a assunção de outras posições de sujeito, o recurso ao discurso reportado, feito com base em um texto veiculado na revista Nova Escola 5 . Por meio desse recurso, traz-se à cena, de forma explícita e mostrada, a voz do outro (da esfera da ciência, um discurso oficial) e a interlocução que com ela estabelece: o eu-narrador reflete sobre o dito do outro, em aberta concordância com ele, bem como sobre as suas implicaçóes na formação de um professor.

A voz, atualizada na forma de um comentário ancorado em um argumento de autoridade, investe-se na posição daquele que julga poder instigar ou aconselhar os pares - colegas em formação - acerca do que é tornar-se professor, e "[...] que todo professor deveria saber [...]". 
Por fim, nesse enunciado, reconhece-se também, da parte do eunarrador, um tom de negociaçáo e valoração, incrementado por uma estratégia de captação relativamente ao que afirma o texto citado: a provocação advinda do texto lido deve ser tomada num bom sentido. É igualmente curiosa a posição-sujeito que aí emerge: temos um sujeito que, para refletir sobre si - ser professor -, coloca-se em relação ao grupo de professores, não como parte dele, mas fora dele. Isto é, o eu-narrador parece ali interpelado por uma voz (saber) que concebe a profissão de professor, pensada sob bases filosóficas e sociológicas, a qual é supostamente desconhecida e/ou ignorada por professores. No gerenciamento dessa voz, no seio da sintaxe de seu discurso, o eu-narrador parece não perceber que o modo como a integra no corpo de sua enunciação acaba por promover a imagem que ele tem de professor. Ao trazer para sua enunciação a enunciação do outro, o aluno parece deixar subentendido que seus pares ainda não sabem "que por trás do trabalho de cada professor, em qualquer sala de aula do mundo, estão séculos de reflexóes sobre o ofício de educar."

Como ilustração, o trecho analisado póe à mostra o quão vozeada é a escrita de memoriais. A polifonia, em graus de orientação e expressividade variados, tende a ser um traço marcante dessa atividade. $\mathrm{O}$ discurso que se atualiza pelo eu-narrador é sempre levado dialogicamente ao discurso do outro, repleto de dicçôes, de entonações, conotações e juízos. Trata-se de processo de orquestração de vozes, por meio do qual se pode ou não assimilar o outro discurso, refutá-lo, fundir-se com ele, o que concorre para que a narrativa se constitua, enquanto forma discursiva, em sua composionalidade, uma rede em que se entrelaçam fios dialógicos. Nesse fenômeno discursivo, marcadamente social, como observa Tezza (1988),

nossas palavras não são 'nossas' apenas; elas nascem, vivem e morrem na fronteira do nosso mundo e do mundo alheio; elas são respostas explícitas ou implícitas às palavras do outro, elas só se iluminam no poderoso pano de fundo das mil vozes que nos rodeiam. (TEZZA, 1988, p. 55). 


\section{Considerações finais}

Do trabalho investigativo aqui descrito, à guisa de conclusão, podese dizer que o memorial é uma atividade discursiva por meio da (e na) qual se dá a conjunção de múltiplos processos - o trabalho da recordação, a emergência da subjetividade e a constituição de posicionamentos identitários. No processo de escrita, alimentado pelas açôes do lembrar, do recordar, emergem movimentos discursivos que póem em cena a atuação de um sujeito que reflete sobre si, sobre o seu processo de subjetividade, sobre seus saberes profissionais. Nesse sentido, parece claro que a subjetividade é a instituição do sujeito enquanto actante/agente enunciativo, aquele que se póe no lugar, que enuncia e assume a palavra. Nesse processo, o laço inalienável sujeito-linguagem é ubíquo, visto que todos os enunciados trazem marcas de um agir fundado numa troca (inter)subjetiva. Tal movimento enunciativo e discursivo, inscrito na composicionalidade da narrativa, dáse à medida que o sujeito dispersa as suas marcas mediante mecanismos vários: os pronomes pessoais, o dispositivo dêitico e, igualmente, as expressóes afetivas, valorativas, apologistas, modalizadoras, interpretativas, que encerram um tom axiológico. Aliado a isso, sob açóes metacognitivas e metadiscursivas, o sujeito elabora e manifesta um saber dizer e um fazer científicos, revelando, aos olhos do interlocutor (e a um analista de seu discurso), o tipo de engajamento que ele cria com o seu próprio dizer e com o dizer do outro. Nesse trabalho de escrita, deixa-se entrever, de igual modo, que a constituição da posição identitária é impossível de se fazer como um todo único e homogêneo.

\section{Notas}

1 Este estudo integra uma frente de pesquisa coordenada por mim, intitulada Os gêneros acadêmicos na formaçáo inicial de professores: dos movimentos de apropriação dos conhecimentos sobre a configuração e funcionamento dos textos aos movimentos de construção de identidade profissional e de autoria. FAPEMIG SHA 198/04 - Fundação de Amparo à Pesquisa de Minas Gerais.

2 Apoiando-se em Pozo, Monereo e Castelló (2004), opera-se aqui com o termo metacognição, numa abordagem que estabelece uma aproximação 
integradora entre as concepçóes cognitivas e socioculturais, de modo que as formas que a pessoa tem de interagir com as tarefas de aprendizagem são entendidas como de natureza social e cultural; a regulação das tarefas deve ser feita considerando o contexto, as demandas e os conteúdos (objetos de ensino) disciplinares de cada situação de aprendizagem.

3 No bojo dos estudos sobre textos memoralísticos, autobiográficos, confissões, diários íntimos, esse termo ganha nuances particulares. Foucault (1992), por exemplo, em artigo intitulado, “A escrita de si”, referindo-se à individualização propriamente dita da memória, remete a uma prática da Antiguidade, os hypomnemata, por meio dos quais se buscava promover uma reflexão fundada no universo da individualidade e no movimento interior do sujeito.

4 Para complementar a discussão, recorre-se ao quadro da psicanálise. De acordo com Freud (1990), recordar implica um processo de repetição, a qual, entretanto, pode inibir ou sabotar um processo de recordação. Repetimos em atos o que não podemos lembrar, o que sinaliza uma resistência, mas é a própria repetição que abre possibilidades para a recordação que, por seu turno, pode dissolver a resistência. Estranhar a repetição, estar atentos a ela, interrogar-se sobre ela, faz-nos aproximar de seus sentidos, das representaçóes em jogo. Isso nos encaminha para a elaboração, o momento de reorganização das representaçóes. Ainda, sob a ótica psicanalítica, relativamente à ação do lembrar, não há como separar o mundo exterior do psiquismo, vez que o exterior nos é apresentado, sob nosso ponto de vista, como interpretação.

5 Nova escola, publicada pela Editora Abril, é uma revista de grande circulação no Brasil, na esfera educacional, destinada a professores da Educação Básica.

\section{REFERÊNCIAS}

ASSIS, J. A; SILVA, J. Q. G. Processo de construção identitária na relação dialógica entre formador e formando. Texto inédito, apresentado no Encontro de pesquisadores do grupo de trabalho "Letramento e Formação de Professor”. Campinas, Unicamp/IEL, 2007. 
BAKHTIN, M. Observações finais. In: BAKHTIN, M. Questóes de literatura e de estética: a teoria do romance. São Paulo: Hucitec/UNESP, 2002. p. 349-362.

BAKHTIN, M. O autor e a personagem. In: BAKHTIN, M. Estética da criação verbal. Tradução de Maria Ermantina Galvão G. Pereira. 4. ed., São Paulo: Martins Fontes, 2003. p. 3-20.

BENJAMIN, W. O Narrador. Consideraçóes sobre a obra de Nikolai Leskov. In: Magia e técnica, arte e política: ensaios sobre literatura e história da cultura. Tradução de Sérgio Paulo Rouanet. 7. ed, São Paulo: Brasiliense, 1994, (Obras escolhidas; v. 1).

BARTLETT, F. Ch. Remembering: a study in experimental and social psychology. Cambridge: Cambridge University Press, 1977.

BOSI, E. Memória e sociedade: lembranças de velhos. 9. ed., São Paulo: Companhia das Letras, 2001.

BRUNER, J.; GREENFIELD, P.; OLVER, R. O. Studies in Cognitive Growth. New York: John Willey e Sons, 1967 [1966].

BURKE, P. A história dos acontecimentos e o renascimento da narrativa. In: BURKE, P. (Org.). A Escrita da História: Novas Perspectivas. São Paulo: Editora da UNESP, 1992, p. 337.

ELIADE, M. Aspectos do Mito. Lisboa: Ed. 70, 1986.

FOUCAULT, Michel. O que é um autor? Trad. Antônio Fernando Cascais, Eduardo Cordeiro. Veja/passagens, 1992.

FRAGO, A.V. Relatos et relaciones autobiograficas de profesores y maestros. In: BENITO, A. E.; DÍAZ, J. M. H. La memória y el deseo: cultura de la esculea y educación deseada. Valencia: Tirant, 2002, p. 135-175. FREUD, S. Recordar, repetir e elaborar. In: Edição Standard Brasileira das Obras Psicológicas Completas de Sigmund Freud. Rio de Janeiro: Imago, 1990. v. 12.

LYOTARD, J. A condição pós-moderna. Rio de Janeiro: J. Olympio, 2002.

MARTINS, A. A. Memórias de professores: eventos e práticas de literacia/letramento. Revista Portuguesa de Educação, ano/vol. 18, número 002. Universidade do Minho, Braga, Portugal. 2005, p. 185-213. 
MISTAL, B. Theories of social remembering. Maidenhead, Philadelphia: Open University Press, 2003.

NÓVOA, A. Os professores e as histórias da sua vida. In. NÓVOA, A. (Org.). Vida de professores. 2. ed. Porto: Porto Ed., 1992.

POLLAK, M. Memória e identidade social. Estudos Históricos. Rio de Janeiro, v. 5, n. 10, 1992. p. 200-212.

POZO, J. I.; MONEREO, C.; CASTELLÓ, M. O uso estratégico do conhecimento. In: COLL, C.; MARCHESI, A.; PALACIOS, J. Desenvolvimento psicológico e educação - psicologia da educação escolar. Porto Alegre: Artmed, 2004. p. 145-160.

RICOUER, P. Autobiografia intelectual. Buenos Aires: Ediciones Nueva Visíon, 1997.

RICOEUR, P. Tempo e Narrativa. Tomo III. Campinas, SP: Papirus, 1997a. p. 360-465.

SIGNORINI, I. O papel do relato no contexto de formação da alfabetização: percurso feito, percurso por fazer. In: KLEIMAN, A, B.; SIGNORINI, I. (Org.). O ensino e a formação de professor alfabetizador de jovens e adultos. Porto Alegre: Artmed Editora, 2000, p. 210-222.

SILVA, J. Q. G; MATENCIO, M. de L. M. Referência pessoal e jogo interlocutivo: efeitos identitários. In: KLEIMAN, A.; MATENCIO, M. de L. M. (Org.). Letramento e Formação do professor. Campinas: Mercado de Letras, 2005.

TEZZA, C. Discurso poético e discurso romanesco na teoria de Bakhtin. In: Uma introdução a Bakhtin. Curitiba: Editora Hatier, 1988.

VYGOTSKY, L. S. Pensamento e linguagem. Tradução J. L. Camargo. São Paulo: Martins Fontes, 1991. 


\section{The memorial in the space of academic graduation: (re)construction of living and identity}

\begin{abstract}
As a point of discussion, we have taken, the written of memorials from early graduation teachers, provided by the actions to remember and to memorize, from which emerge the discursive movements which act as a play of an individual which reflect on himself and his own knowledge. On this aspect, the memorial is seen as a productive methodological way by providing the researcher a comprehension around the movements of the his/her identity process, from the teacher's point of view, guided therefore by his/her eyes. On this written activity, an enunciative and metadiscursive actuation game is identified, which reveals, to the reader, the type of engagement that the individual creates with his own saying or with others, with his/her professional knowledge.
\end{abstract}

Keywords: Memorial. Professional identity graduation. Metadiscursive actions.
La memoria en el espacio de la formación académica: (re) construcción de lo vivido y de la identidad

\section{Resumen}

El objeto de discusión del presente texto es la escrita de la memoria de los docentes en su formación inicial, alimentada por las acciones de recordar, de las cuales emergen movimientos discursivos que ponen en escena la actuación de un sujeto que reflexiona sobre si mismo y sobre sus saberes profesionales. La memoria, en ese contexto, es vista como un recurso metodológico productivo que proporciona al investigador una comprensión acerca de los movimientos del proceso de la formación de la identidad profesional, a partir del punto de vista del docente, guiado, por lo tanto, por la mirada de ese sujeto. En esa actividad de escrita se identifica un juego de actuación anunciativa y metadiscursiva que revela, al lector, el tipo de compromiso que el sujeto cria con su propoio decir y/o con el decir del otro, con su saber profesional.

Palabras claves: Memoria. Formación docente. Acciones meta-discursivas.

\section{Jane Quintiliano Guimarães Silva}

E-mail: janequinguimaraes@yahoo.com.br

Recebido em: 1/7/2010

Aprovado em: 22/10/2010 